\title{
A population study in cotton ginnery workers in the Sudan
}

\author{
MUSTAFA KHOGALI \\ Faculty of Medicine, University of Khartoum
}

\begin{abstract}
Khogali, M. (1969). Brit. J. industr. Med., 26, 308-313. A population study in cotton ginnery workers in the Sudan. An epidemiological study in cotton ginneries in the Sudan covered 323 permanently employed ginnery workers, a random sample of 35 seasonal farfara workers, and a control group of 24 members of a fire brigade. All the workers studied were men.

The study showed a prevalence of byssinosis (defined as chest tightness starting on return from the annual holiday and continuing for at least three consecutive days) in $20 \%$ of the ginnery workers and in $48.6 \%$ of the farfara workers. Workers exposed to dust showed a mean fall in F.E.V.1.0 of -0.10 litre during the shift, while workers not so exposed showed a mean rise of +0.23 litre; this difference was statistically significant. The F.E.V.1.0 was adjusted for age and standing height. The adjusted means of F.E.V.1.0 were significantly lower for workers exposed to dust compared with those in the control group.

The workers with byssinosis showed a statistically significant fall in F.E.V.1.0 when compared with all ginnery workers; and a highly significant fall when compared with cotton workers without chest symptoms. An attempt was made to grade the byssinotics according to the extent of fall in F.E.V.1.0 during the shift.

The concentration of fine dust $(<7 \mu)$ was measured in each work place. There was a statistically significant association between the prevalence of byssinosis and the concentration of fine dust when comparing the ginnery and farfara workers. Also, there was a significant relationship between the mean adjusted F.E.V.1.0, the mean fall in F.E.V.1.0, and the fine dust concentration.
\end{abstract}

Cotton cultivation was introduced to the Sudan on a large scale in late 1925 . The area cultivated is approximately half a million acres, which yield two million kontars (one kontar $=100 \mathrm{lb} .=45.36 \mathrm{~kg}$.) of cotton every year. The cotton is ginned in two main centres in the Gezira. One hundred million pounds of cotton are ginned in the Maringan Ginning Factories where this study was made.

There are five factories in Maringan, four of them built since 1925 and one in 1960. Each factory occupies an area of 5,000 sq. metres. Two factories have 106 gins each and the other three have 92 gins. The gins are situated in ginnery halls which have workshops opening directly into them.

Ginning is seasonal. Work starts in January and finishes at the end of May, being continuous 24 hours a day, seven days a week.
The ginning process is the same as that described by Batawi (1962) but here the farfara process follows ginning which is the opposite of the Egyptian practice (Batawi, Schilling, Valic, and Walford, 1964). Cotton is ginned to separate the seed from the lint before being passed into belts for mixing and farfara. After farfara it is pressed into bales ready for export.

The prevalence of byssinosis in cotton ginneries has been described in many different countries (Gilson, Stott, Hopwood, Roach, McKerrow, and Schilling, 1962; Batawi, 1962; Batawi et al., 1964; Kondakis and Pournaras, 1965). In the Sudan, byssinosis caused by cotton dust is a notifiable and compensatable industrial disease under the Workshops and Factories Ordinance, 1949 (Khogali, 1966). There has been no attempt to measure the size of the problem; and no epidemiological study 
has been made before the one now reported, which was started in April, 1967.

\section{Population}

Ginnery workers were divided into two main groups permanent and seasonal. The permanent group, numbering 353 workers in Maringan, is employed by the Gezira Board. Nearly one fifth of these men work in the ginnery workshop and comprise electricians, fitters, mechanics, and their assistants. The remainder work in the ginnery factory itself and they comprise the gin and pressmen and their assistants. These workers stay between the gins for the whole of each shift.

The seasonal workers are employed by the contractor for jobs such as transporting cotton from the field, mixing, ginning, and farfara. The newly built factory is mechanized without a farfara process. Our aim was to study all the permanent workers and out of 353 we were able to examine fully $323(92 \%)$. A random sample of 35 was selected from the farfara workers. The fire brigade workers were taken as a control group: 24 out of 25 were examined. These men live under the same conditions as the ginnery workers and are socially and economically very similar. All workers examined in the study were men.

\section{Plan of study}

The examination of workers in the different groups was standardized. For each worker, social and personal data were recorded, including an occupational history. Past medical history and smoking habits were taken into account. A questionnaire on chest symptoms (Schilling, Vigliani, Lammers, Valić, and Gilson, 1964), translated into Arabic, was used.

The questionnaire was followed by a complete physical examination and measurements of height, weight, and blood pressure. As these workers work seven days a week without a weekend break, byssinosis was diagnosed on a history of chest tightness starting on return from the annual holiday and continuing for at least three consecutive days during the first week of ginning.

\section{Respiratory function tests}

The forced expiratory volume (F.E.V.1.0) and the forced vital capacity (F.V.C.) were measured using the Vitalograph. Workers were instructed on the use of the Vitalograph in groups of five at the same time as the questionnaire and physical examination and each practised using it. Measurements were done at the factory at the start of each shift and at the end of the working day. Results were recorded on separate graph sheets.

Each worker first made two trial blows and then three measurements were recorded. The mean of the two highest readings out of three was taken (Bouhuys, Heaphy, Schilling, and Welborn, 1967). All readings were corrected to B.T.P.S. Dry and wet bulb temperatures inside and outside the factory were recorded every six hours using a whirling hygrometer.

\section{Dust measurement}

The mass of fine dust ( $<7$ microns) was measured using a hexhlet dust sampler (Roach and Schilling, 1960). In each factory two measurements were taken during each shift, one in the ginnery hall and one in the farfara section. Only two samples were taken in the ginnery workshops because of the shortage of time available for the study.

The hexhlet was always sited 5 feet $(1.5 \mathrm{~m}$.) above the floor. Samples were obtained over an eight-hour period. It could not be maintained during the 12-hour period of the shift as the air temperature was high and the generator became very hot.

\section{Results}

\section{General}

The mean age and mean job duration for each group are given in Table 1. Forty-seven per cent. of the workers are in the age group 25-34 which is in accordance with the age of the economically active population in the Sudan. The permanent workers are pensioned at 55 years.

\section{Chest symptoms and byssinosis}

The prevalence of chest symptoms in the workers examined is shown in Table 2 together with the proportion of smokers. A substantial number had symptoms of byssinosis, ranging from 10 out of 52 $(19 \%)$ in the ginnery workshops, 55 out of 271 $(20 \%)$ in the ginnery hall, and 17 out of $35(49 \%)$ in the farfara section. In the farfara section the prevalence of byssinosis is nearly the same as in the farfara process at Egyptian ginneries (Batawi et al., 1964) (Table 3).

\section{Physiological results}

An analysis of variance showed statistically significant differences between the change in F.E.V.1.0 of the three groups of cotton workers and the control group (P < 0.05) (Table 4).

The mean change in F.E.V.V.1.0 during the shift for workers exposed to dust is significantly greater than for the workers not exposed $(0.01>\mathrm{P}>0.001)$.

\section{TABLE 1}

Age and Job Duration of Workers in Maringan COTTON GinNeries

\begin{tabular}{l|l|c|c|c}
\hline Work place & $\begin{array}{c}\text { Nature } \\
\text { of job }\end{array}$ & $\begin{array}{c}\text { Total no. } \\
\text { examined }\end{array}$ & $\begin{array}{c}\text { Mean } \\
\text { age } \\
(y r s)\end{array}$ & $\begin{array}{c}\text { Mean } \\
\text { job } \\
\text { duration } \\
(y r s)\end{array}$ \\
\hline $\begin{array}{l}\text { Controls } \\
\text { Ginnery } \\
\text { workshop }\end{array}$ & Permanent & 24 & 35 & 13 \\
Ginnery hall & Permanent & 52 & 33 & 11 \\
Farfara & Seasonal & 35 & 30 & 6 \\
& Total & 382 & & \\
\hline
\end{tabular}


TABLE 2

Byssinosis and Chest Symptoms among Workers Exposed to Cotton Dust AND AMONG THE CONTROLS

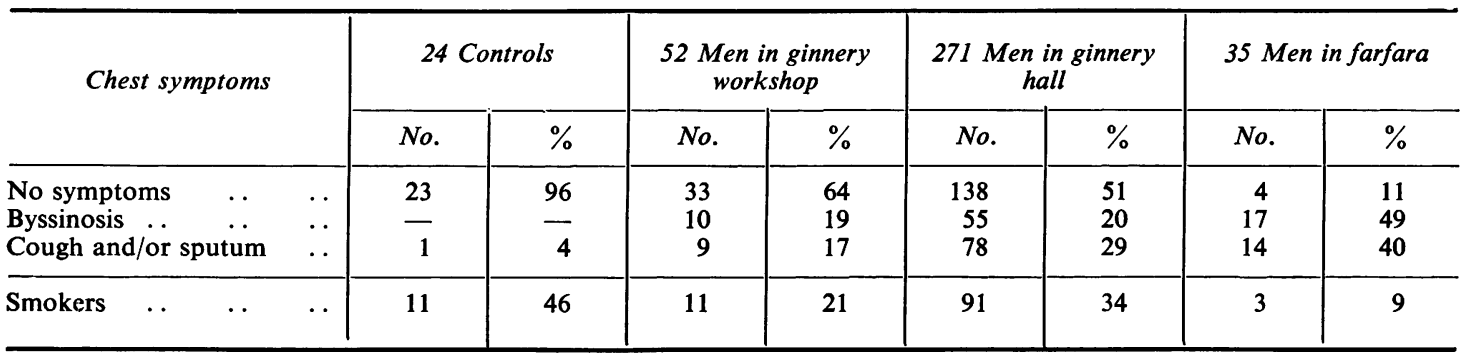

TABLE 3

Prevalence of Byssinosis in Workers in the Ginning and Farfara Process In CotTon GinNeries IN EGYPT AND the SUdAN

\begin{tabular}{|c|c|c|c|c|c|c|c|c|}
\hline \multirow[b]{2}{*}{ Observer } & \multicolumn{4}{|c|}{ Ginning } & \multicolumn{4}{|c|}{ Farfara } \\
\hline & $\begin{array}{c}\text { No. } \\
\text { of } \\
\text { workers }\end{array}$ & $\begin{array}{c}\text { Mean } \\
\text { age } \\
(y r s)\end{array}$ & $\begin{array}{c}\text { Mean } \\
\text { exposure } \\
(y r s)\end{array}$ & $\begin{array}{l}\text { Byssinosis } \\
(\%)\end{array}$ & $\begin{array}{c}\text { No. } \\
\text { of } \\
\text { workers }\end{array}$ & $\begin{array}{l}\text { Mean } \\
\text { age } \\
(y r s)\end{array}$ & $\begin{array}{c}\text { Mean } \\
\text { exposure } \\
(y r s)\end{array}$ & $\begin{array}{l}\text { Byssinosis } \\
(\%)\end{array}$ \\
\hline $\begin{array}{l}\text { Batawi (1962) } \\
\text { Batawi, Schilling, Valic, and }\end{array}$ & 323 & - & 9 & 38 & - & - & - & - \\
\hline Khogali (1966) .. & 271 & 31 & 9 & $20^{1}$ & 35 & 30 & 6 & 49 \\
\hline
\end{tabular}

${ }^{1}$ See text for definition of byssinosis in these workers.

\section{TABLE 4}

Mean F.E.V.1.0 Adjusted for Age and Height and Mean Change during a Shift in Workers in Maringan Cotton GinNeries

\begin{tabular}{|c|c|c|c|}
\hline \multirow{2}{*}{ Work place } & \multirow{2}{*}{$\begin{array}{c}\text { No. of } \\
\text { workers }\end{array}$} & \multicolumn{2}{|c|}{ Mean F.E. $V_{\cdot 1 \cdot 0}(l)}$. \\
\hline & & $\begin{array}{l}\text { Adjusted for } \\
\text { age and } \\
\text { height }^{1}\end{array}$ & $\begin{array}{c}\text { Change } \\
\text { during } \\
\text { shift }^{2}\end{array}$ \\
\hline $\begin{array}{l}\text { Controls .. } \\
\text { Ginnery workshop } \\
\begin{array}{ll}\text { Ginnery hall } \\
\text { Farfara .. }\end{array}\end{array}$ & $\begin{array}{r}24 \\
52 \\
271 \\
35\end{array}$ & $\begin{array}{l}3 \cdot 08 \\
3 \cdot 02 \\
2 \cdot 77 \\
2 \cdot 20\end{array}$ & $\begin{array}{l}+0.23 \\
-0.04 \\
-0.10 \\
-0.22\end{array}$ \\
\hline
\end{tabular}

${ }^{1}$ F.E. $V_{1 \cdot 0}$ adjusted to standard age of 31 years and height $171 \mathrm{~cm}$.

Significance levels of the mean F.E.V.1.0:

Ginnery hall $v$. control $(\mathrm{t}=2.76) \mathrm{P}<0.01$.

Farfara $v$. control $(t=4.11) P<0.001$.

${ }^{2}$ Significance levels for differences between mean changes: Ginnery workshop $v$. control $(t=1.91)$ Not significant

Ginnery hall $v$. control $(t=2.71) 0.01>P>0.001$.

Farfara $v$. control $(t=2.96) 0.01>P>0.001$.
Significant differences in the mean change were also found when comparing workers in the ginnery hall with the controls $(0.01>P>0.001)$ and the farfara workers with the controls $(0.01>P>0.001)$. Although workers in the workshops had a fall in F.E.V.1.0, the difference was not significant when compared with that of the controls.

The initial observed F.E.V.1.0 for ginnery workers was significantly less than for the controls $(P<0.01)$. But as the F.E.V.1.0 decreases with age and increases with height the observed values were adjusted to allow for differences in age and height using a standard age of 31 years and a height of $171 \mathrm{~cm}$. The regression of F.E.V.$_{1 \cdot 0}$ on age independent of height was -0.023 litre per year. The regression on height independent of age was $+0.0361 . / \mathrm{cm}$. (Table 4). The overall difference between the adjusted means was still significant $(P<0.001)$. The significance level was high when comparing the adjusted mean F.E.V.1.0 of farfara workers with that of the controls $(\mathrm{P}<0.001)$. The difference was also significant when the controls were compared with ginnery hall workers $(P<0.01)$ but not significant when they were compared with the workshop workers. 
In accordance with the findings of Schilling (1962) the mean fall in ventilatory capacity was more pronounced for byssinotics than for normal workers exposed to dust (Table 5). This difference was found to be statistically significant on comparison of the mean change in F.E.V.1.0 in byssinotics with that in all ginnery workers $(0.05>\mathrm{P}>0.02)$; it was highly significant when comparing byssinotics with normal ginnery workers $(0.01>P>0.02)$; it was highly significant when comparing byssinotics with normal ginnery workers $(0.01>\mathrm{P}>0.001)$.

The mean change in F.E.V..$_{1 \cdot 0}$ in normal ginnery workers was not statistically significant on comparison with the controls (Table 5). But the difference was statistically highly significant $(P<0.001)$ when comparing byssinotics with controls.

The fall in F.E.V.1.0 was marked in the byssinotics (Table 5) as has been observed before (Bouhuys, Lindell, and Lundin, 1960; McKerrow and Schilling,

\section{TABLE 5}

Change in F.E.V.1.0 DURING Shift in Men with AND WITHOUT BYSSINOSIS, AND IN CONTROL GROUP

\begin{tabular}{l|c|c|c}
\hline Group & $\begin{array}{c}\text { No. of } \\
\text { workers }\end{array}$ & $\begin{array}{c}\text { Mean } \\
\text { exposure to } \\
\text { dust }(y r s)\end{array}$ & $\begin{array}{c}\text { Mean } \\
\text { change in } \\
\text { F.E.V.1.0 } \\
\text { during shift }{ }^{1}\end{array}$ \\
\hline Controls . . .. & 24 & 0 & +0.23 \\
Without byssinosis & 276 & 9.4 & -0.06 \\
With byssinosis .. & 82 & 8.7 & -0.25 \\
\hline
\end{tabular}

${ }^{1}$ Byssinotics $v$. all ginnery workers $0.05>P>0.02(t=2 \cdot 12)$. Byssinotics $v$. normal ginnery workers $0.01>P>0.001$ $(\mathrm{t}=2 \cdot 70)$.

Byssinotics $v$. controls $P<0.001(t=3.53)$.

Normal ginnery workers $v$. controls - Not significant.
1961; Gilson et al., 1962). Thus a further gradation of workers with byssinosis was done on the basis of the extent of the fall in F.E.V.1.0. The proportion of byssinotics with a fall in F.E.V.1.0 greater than $0 \cdot 20$ litre is shown for each job group in Table 6. The mean fall in F.E.V.1.0 during the shift, in the byssinotics with a fall of more than $0 \cdot 20$ litre, showed no significant difference between the jobs. A significant difference was observed when comparing the mean fall in F.E.V.1.0 of all byssinotics (Table 6) in each group. This may indicate that the disease, in byssinotics with a fall greater than $0 \cdot 20$ litre in F.E.V.1.0 during the shift, attains a more stable form and could easily be compared in different groups.

\section{Dust concentration}

Table 7 shows the fine dust ( $<7$ microns) concentration in the different work areas. The concentration in the farfara section was four times the concentra-

TABLE 6

Byssinosis Prevalence in Maringan Cotton GINNERY WORKERS

\begin{tabular}{|c|c|c|c|}
\hline Work place & $\begin{array}{c}\text { No. of } \\
\text { workers }\end{array}$ & $\begin{array}{c}\text { With } \\
\text { byssinosis } \\
(\%)\end{array}$ & $\begin{array}{c}\text { Byssinotics } \\
\text { with fall in } \\
\text { F.E.V } \cdot 1 \cdot 0 \\
\text { during shift } \\
>0 \cdot 20 \text { litre } \\
(\%)\end{array}$ \\
\hline $\begin{array}{l}\text { Ginnery workshop } \\
\text { Ginnery hall } \\
\text { Farfara }\end{array}$ & $\begin{array}{r}52 \\
271 \\
35\end{array}$ & $\begin{array}{l}19^{1} \\
20 \\
49\end{array}$ & $\begin{array}{l}30^{2} \\
42 \\
82\end{array}$ \\
\hline
\end{tabular}

${ }^{1}$ All byssinotics in ginnery workshop $v$. all byssinotics in farfara $P<0.01(t=3.32)$.

All byssinotics in ginnery hall $v$. all byssinotics in farfara $P<0.001(t=3.48)$.

${ }^{2}$ No significant difference between the groups.

TABLE 7

Dust Concentration, Change in F.E.V.1.0, and Prevalence of Byssinosis in Workers EXPOSED TO COTTON DUST

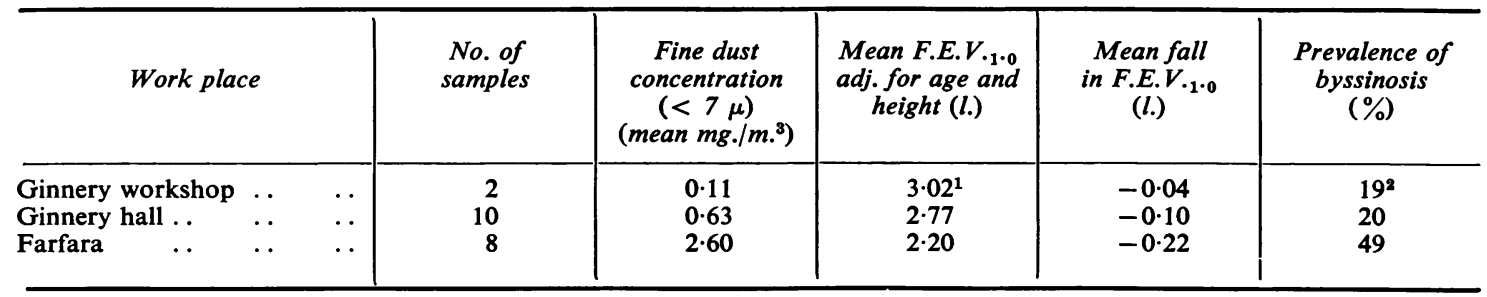

${ }^{1}$ Significance levels comparing different means were:

Ginnery workshop $v$. ginnery hall $\mathrm{P}<0.05(\mathrm{t}=2 \cdot 19)$.

Ginnery workshop $v$. farfara $P<0.001(t=4.87)$.

Ginnery hall $v$. farfara $P<0.001(t=4.07)$.

2Results of paired comparisons were:

Prevalence of byssinosis in ginnery workshop $v$. farfara $P<0.01\left(\chi^{2}=7 \cdot 10\right)$.

Prevalence of byssinosis in ginnery hall $v$. farfara $P<0.001\left(\chi^{2}=12 \cdot 25\right)$.

Prevalence of byssinosis in ginnery workshop $v$. ginnery hall - Not significant. 
tion in the ginnery hall and 20 times the concentration in the ginnery workshops. The respirable fine dust $(<7 \mu)$ has the same effect as the total dust (McKerrow, Roach, Gilson, and Schilling, 1962).

There is a positive association between the prevalence of byssinosis and the fine dust concentration in different work areas (Table 7). Applying the overall Chi square test, the difference in byssinosis prevalence between jobs was significant $(P<0.001$; $\chi^{2}=14 \cdot 50$ ). A comparison of pairs of jobs, using the Chi square test with correction for continuity, showed a significant difference between workers in the workshop and in the farfara $(P<0.01)$ and between workers in the ginnery hall and in the farfara $(P<0.001)$.

There is also an association between the fine dust concentration and the adjusted mean F.E.V.1.0 (Table 7 and Fig. 1). There were significant differences between the mean F.E.V.1.0 workshop and the ginnery hall $(\mathrm{P}<0.05)$; between those in the workshop and in the farfara $(P<0.001)$; and between. workers in the ginnery hall and in the farfara $(P<0.001)$. There were also significant differences in the mean change of F.E.V.1.0 during the shift related to the level of dust concentration (Fig. 2).

\section{Discussion}

The prevalence of byssinosis in the farfara process is nearly the same as that found in the farfara at Egyptian cotton ginneries (Batawi et al., 1964). But the prevalence of byssinosis in the ginnery halls is less than that reported in Egypt. Kondakis and Pournaras (1965) did not find byssinosis in cotton ginneries in Greece.

Table 3 shows the prevalence of byssinosis in the main processes of ginning and farfara in Egypt and

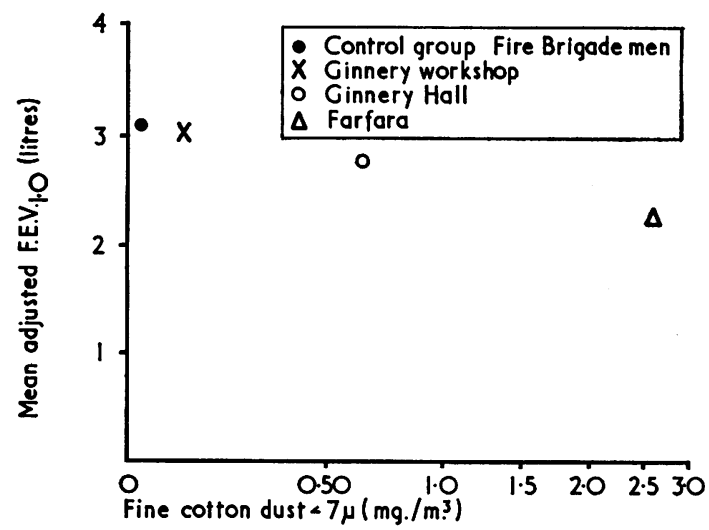

FIG. 1. Relationship between fine dust concentration and mean adjusted F.E.V.1.0 in Maringan ginnery workers. in the Sudan. Batawi (1962) found that the prevalence of chronic bronchitis in his group of the ginnery workers was $16.7 \%$. In our study $10.2 \%$ complained of cough and sputum but could not be classified as having chronic bronchitis according to the Medical Research Council classification (M.R.C., 1965). The prevalence of byssinosis did not appear to be related to smoking habits. Only $30 \%$ of the workers exposed to dust smoked, compared with $46 \%$ of the controls. Only six workers smoked more than $15 \mathrm{~g}$./day and the majority smoked less than $10 \mathrm{~g}$./day. A substantial number $(40 \%)$ used snuff as smoking is prohibited in the ginning area.

A comparison between the dust concentration in this study and in earlier studies in ginneries was difficult. Batawi et al. (1964) measured the total dust. Gilson et al. (1962) reported both fine and medium dust combined together in two out of three ginneries studied. In the third ginnery a special type of cotton fifi was ginned - the fine dust concentration was $1.11 \mathrm{mg} . / \mathrm{m}^{3}$ (19\% of total dust). Nevertheless byssinosis was not diagnosed, but there was a highly significant fall in the ventilatory capacity. Kondakis and Pournaras (1965) did not report any dust measurements. Evidently more studies including dust measurements are needed in the cotton ginneries. The maximum allowable concentration for cotton dust is accepted as $1 \mathrm{mg} . / \mathrm{m}^{3}$ (Roach and Schilling, 1960). The percentage by weight of fine dust to total in that study was only $6 \%$.

We are planning to study the same population again this year from the beginning of the season to its close to compare the cumulative effect of continuous exposure to different grades of cotton dust during the ginning season.

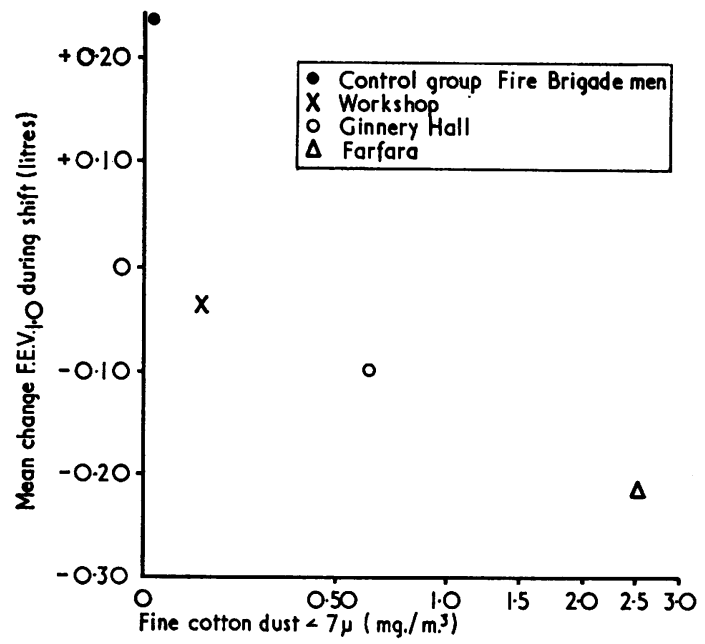

FIG. 2. Relationship between fine dust concentration and mean change in F.E.V.1.0 in Maringan ginnery workers. 
The study was made possible by the willing co-operation of the management and employees of the Gezira Board and I wish to acknowledge the help given by the Governor and staff. Help was also given by Dr. M. E. Mahdi and Dr. H. Hussein, chest physicians in the Sudan. I wish to thank Dr. V. H. Hawthorne for his help. Also many thanks are due to Miss J. Walford and Miss R. Wood for their statistical analysis and to Professor R. S. F. Schilling for his advice.

\section{References}

Batawi, M. A. El (1962). Byssinosis in the cotton industry of Egypt. Brit. J. industr. Med., 19, 126-130.

- Schilling, R. S. F., Valić, F., and Walford, Joan (1964). Byssinosis in the Egyptian cotton industry: changes in ventilatory capacity during the day. Ibid., 21, 13-19.

Bouhuys, A., Heaphy, L. J., Schilling, R. S. F., and Welborn, J. W. (1967). Byssinosis in the United States. New Engl. J. Med., 277, 170-175.

, Lindell, S. E., and Lundin, G. (1960). Experimental studies on byssinosis. Brit. med. J., 1, 324-326.
Gilson, J. C., Stott, H., Hopwood, B. E. C., Roach, S. A., McKerrow, C. B., and Schilling, R. S. F. (1962). Byssinosis: the acute effect on ventilatory capacity of dusts in cotton ginneries, cotton, sisal, and jute mills. Brit. J. industr. Med., 19, 9-18.

Khogali, M. (1966). The future of an occupational health unit in Khartoum University, The Sudan. Ibid., 23, 154-158.

Kondakis, X. G., and Pournaras, N. (1965). Byssinosis in cotton ginneries in Greece. Ibid., 22, 291-294.

McKerrow, C. B., Roach, S. A., Gilson, J. C., and Schilling, R. S. F. (1962). The size of cotton dust particles causing byssinosis: an environmental and physiological study. Ibid., 19, 1-8.

- and Schilling, R. S. F. (1961). A pilot enquiry into byssinosis in two cotton mills in the United States. J. Amer. med. Ass., 177, 850-853.

M.R.C. Committee on the Aetiology of Chronic Bronchitis (1965). Definition and classification of chronic bronchitis. Lancet, 1 , 775-779.

Roach, S. A., and Schilling, R. S. F. (1960). A clinical and environmental study of byssinosis in the Lancashire cotton industry. Brit. J. industr. Med., 17, 1-9.

Schilling, R. S. F. (1962). Case Study No. 2: Field studies of byssinosis. J. occup. Med., 4, 627-637.

, Vigliani, E. C., Lammers, B., Valić, F., and Gilson, J. C. (1964) $A$ report on a conference on byssinosis (Manchester, 1962). In Proc. XIVth int. Congr. occup. Hlth, Madrid, 1963, Vol. 2, pp. 137-145. International Congress Series No. 62. Excerpta Medica Foundation, Amsterdam.

Received for publication December 31, 1968. 